\title{
Harmonization of Direct Taxation in the EU
}

\author{
MSc. Matjaž Kovač \\ doctoral candidate for finance and tax law at the Faculty of Law, University of Maribor; \\ a higher education lecturer for the subjects area Law at Alma Mater Europea; \\ managing director of LEKSIAKOV, legal, business, financial and tax services 1.t.d. \\ Knafelčeva 30, Maribor, Slovenia
}

\begin{abstract}
Direct taxes (personal income tax, corporation tax, capital tax) are paid on income and capital flows. Direct taxation interferes with fundamental freedoms, namely the free movement of persons (natural or legal) and the free movement of capital. In the common market, not only work and entrepreneurship are subject to the right of free movement, but also capital. Investors should be able to invest their money where they think the risk/return ratio is best. In addition, the right of establishment establishes the need for the free movement of capital, which usually involves the cross-border movement of capital (assets). In presenting article I will discuss about different types of direct tax harmonization: harmonization of taxation of mergers, divisions, transfers of funds and exchanges of shares of companies from different Member States, harmonization of the tax system of parent and subsidiaries, harmonization of the system of taxation of interest payments and royalties of related companies, and harmonization corporate income tax bases (CCCTB)
\end{abstract}

Keywords: Fundamental Freedoms, Common Market, Harmonization of Taxes, Direct Taxes, CCCTB 


\section{Introduction}

Tax policy coordination is one of the basic elements that can contribute to greater economic integration with the European Union. The Treaty of Rome establishing the European Economic Community (EEC, EU and Community), provides in Article 2 that the EEC should, as its primary task, establish a common market by gradually approximating the economic policies of the Member States, as well as promoting a harmonious economic development, balanced economic growth, increased stability, accelerated raising of the standard of living and closer relations between the countries belonging to it. These activities stipulate that Member States must remove all obstacles to the free movement of products, services, people and capital (four fundamental freedoms). Taxes and customs duties levied by Member States on a national basis may be one of the most important obstacles to the exercise of the four freedoms of the Treaty of Rome.

With regard to direct taxation, the European Union accepts some tacit agreement that the reconciliation of personal income tax and social contributions should not directly affect these benefits, which still need to be organized at national level. However, the harmonization of corporate taxation is indirectly reflected in Article 100 of the Treaty of Rome, which provides that the EU Council, acting unanimously on a proposal from the Commission, shall enact directives relating to the approximation of those provisions of laws, regulations or administrative provisions in the Member States which directly affect the establishment or functioning of the common market ${ }^{1}$.

Since the establishment of the EU, corporate taxation has received particular attention, as this is one of the most important elements for the establishment and completion of the internal market. The Neumark Report published in 1962 in the field of corporate taxation includes several recommendations regarding the field of corporate taxation. The Tempell Report, issued in 1970, suggested a number of initiatives aimed at achieving a limited degree of harmonization of the corporate tax system, the creation of a tax base and tax rates ${ }^{2}$.

In 1975, the Commission put forward appropriate proposals for directives recommending a single statutory corporate tax rate of between 45 and 55 percent, a partial credit imputation system modeled on the French fiscal method with a single tax rate for a company shareholder on distributed dividends and a $25 \%$ withholding tax on all other dividends other than dividends transferred by subsidiaries to a parent company situated in one of the Member States. However, the proposal for a 1975 directive was never adopted because the EEC was of the opinion that, before adjusting tax rates, it was necessary to harmonize the rules for determining the tax base.

\footnotetext{
${ }^{1}$ Auerbach A. J., The Future of Capital income Taxation, Fiscal Studies 27(4), p. 399-420.

${ }^{2}$ Deweraux M.P., Griffith R, Klemm A., (2002) Corporate Income Tax Reforms and International Tax Competition, Economic Policy, 35, p. 451-495.
} 
In the following, the EEC focused more on the system of loss settlement and proposed a directive on the carry forward of losses to future tax periods. The European Commission has proposed the harmonization of the legislation to carry forward the loss for three years and to carry out the loss indefinitely in subsequent tax periods. The preldog was unfortunately subsequently withdrawn.

In 1988, the European Commission came up with a proposal to harmonize the corporate tax base, which was never implemented because of the unwillingness to accept most Member States.

In 1990, the European Commission temporarily abandoned the broad objective of harmonizing corporate tax and instead focused on eliminating the remaining forms of double taxation. It made recommendations in three main areas, namely; the elimination of tax obstacles to cross-border investments and interests within the Community, the establishment of a minimum legal tax rate of $30 \%$ on corporate income tax and the development of common rules for calculating the tax base in order to avoid excessive tax competition. Among the three objectives mentioned above, some progress has been made on the first objective only ${ }^{3}$.

The EU Treaty does not contain specific legislative powers in the field of direct taxation. Corporate taxation law is based on Article 115 TFEU, which is the basis for a directive on the approximation of those laws, regulations and administrative provisions of the Member States which directly affect the establishment or functioning of the internal market, and provides for agreement and consultation. Article 65 TFEU concerns the free movement of capital and allows Member States to treat taxpayers who are not in the same position differently from the place of residence or place where their capital is invested. Articles 110 to 113 of the TFEU require Member States to enter into negotiations on the elimination of double taxation in the Community, and Article 55 prohibits discrimination on grounds of equity participation in undertakings. Most direct taxation rules do not, however, fall within the scope of Community law. A considerable number of bilateral tax treaties concluded by Member States with each other or with third countries concern the taxation of cross-border revenue.

Proposals for the harmonization of corporate taxation have been the subject of debate for over 30 years (1962: Neumark Report, 1970: Van den Templ Report, 1975: proposal for a directive on the harmonization of tax rates between 45 and 55\%). In 1980, the Commission stated in its Communication that this attempt at harmonization was likely to be a failure (COM (80) 139). It therefore focused on the limited measures strictly necessary to complete the internal market. The 1990 Company Tax Guidelines (SEC (90) 601) gave priority to three previously published proposals, which were subsequently adopted, the Merger Directive

\footnotetext{
${ }^{3}$ Kind H.J., Midelfart K.H., Schjelderup G. Corporate Tax System, Multinational Enterprises and Economic Integration, Journal of International Economics, Elsevier 65(2), pp. 507-521.
} 
(90/434 / EEC), which deals with capital gains in mergers, the Parent and Subsidiaries Directive (90/435 / EEC), which eliminates the double taxation of dividends paid by a subsidiary in one Member State to a parent company in another Member State, and the Arbitration Convention (90/436 / EEC), establishes a procedure for the settlement of disputes concerning the profits of affiliated companies. The fierce debate between Member States is reflected in the 1991 proposed directive on interest and royalties paid by parent and subsidiary companies: although the proposal was amended two years later and endorsed by the European Parliament, the Commission subsequently withdrew it, since the Council could not agree on it. In 1998, a new version of the proposal was adopted as part of the Monti package, which was adopted as Directive 2003/49 / EC.

In 1991, the Rudding Committee of Independent Experts was set up, which in its report proposed a work program to eliminate double taxation, to harmonize corporate tax rates from 30 to $40 \%$, and to ensure full transparency of the various Member States' tax breaks in order to encourage investment. The Commission then proposed amendments to the Directives on mergers and / or parent and subsidiaries (COM (93) 293), and referred to two proposals for directives that had been tabled recently, namely the transfer of losses (COM (84) 404) and the losses of business units and subsidiaries in other Member States (COM (90) 595). In 1996, the Commission introduced a new approach to taxation. In the area of corporate taxation, its main result was the Code of Conduct on Business Taxation, adopted as a Council Resolution in 1998. The Council established a Codex Preparation Group (the "Primarolo Group") to investigate cases of unfair corporate income taxation. She presented her report in 1999, identifying as many as 66 tax procedures that are expected to be eliminated in five years. In 1998, Member States asked the Commission to produce an analytical study of corporate income taxation in the European Community. The study, prepared by two expert groups (SEC (2001) 1681), was published in 2001. In an accompanying communication (COM (2001) 582), the Commission found that the main problem for businesses stemmed from the fact that to face different national rules in the internal market. The Commission has proposed a number of different approaches to provide businesses with a common basis for their activities in the EU: home country taxation, optional common consolidated tax base, European corporate tax or a mandatory and fully harmonized tax base. The proposals were discussed at a conference in 2002. A working group was also set up in 2004 and its results were published in the Commission proposal for a directive (COM (2011) 121). The proposed "Common Consolidated Corporate Tax Base" (CCCTB) would mean that businesses would have, inter alia, a single tax administration system where they could file a tax refund claim. It could also consolidate all profits and losses from operating in the EU. Member States would fully retain the power to set corporation taxes.

2 Harmonization of taxation for mergers, divisions, transfers of funds and exchanges of shares of companies in different Member States

In the Member States of the European Union, tax neutrality in the status changes is required in a specific guideline or directive, which stipulates that the tax system and fiscal policy must play a neutral role in the transformation of companies. This area is covered in detail in Directive 90/434 / EEC (as amended) on the common system of taxation applicable to mergers, divisions, 
transfers of funds and exchanges of shares of companies from different Member States. The basic premise of the directive is that mergers, divisions, transfers of funds and exchanges of shares in capital companies should not lead to taxation. The Directive facilitates reorganizations (mergers, divisions, transfers of assets, exchanges of shares) by deferring taxation under certain conditions (for example, capital gains on an asset are not taken into account in a merger or division but only at a later sale). Other companies (not limited-liability companies whose capital is securities) may also apply a more favorable tax regime, such as limited liability companies. The EU's solution to this directive was not to tax capital gains when the merger or payment of funds occurs, but to recover those gains ${ }^{4}$. This solution is interesting for the creation of "European companies", since many businesses are usually created by merging companies originally established in different Member States ${ }^{5}$.

In 2005, the Directive was amended ${ }^{6}$. This Directive also extends to the transfer of the registered office of a European company (SE) and a European cooperative society (SCE) from one Member State to another, and also provides for an exemption from capital gains tax where the acquiring company owns shares in the transferring company .

\section{Harmonization of the tax system of parent and subsidiaries}

Council Directive 90/435 / EEC of 23 July 1990 on the common system of taxation applicable in the case of parent companies and subsidiaries of different Member States has been substantially amended several times ${ }^{7}$. In order to create conditions in the Community similar to those in the internal market and thus ensure the effective functioning of such an internal market, integration into groups of companies from different Member States is necessary. These operations must not be hampered by restrictions, deficiencies or distortions arising primarily from Member States' tax rules. Therefore, such mergers into groups of companies from different

\footnotetext{
${ }^{4}$ In the case of Hans Markus Kofoed v Skatteministeriet (C 321/05), the Court of Justice ruled that profits paid to the shareholders of the acquired company shortly after the change of capital, but not an essential part of the consideration to be paid by the acquiring company, were not may be included in the calculation of the "cash payment" provided for in Article 2 of the Directive, as this means "exchange of capital shares". Therefore, Article 8 of this Directive precludes the taxation of such exchange of shares, unless tax evasion or avoidance in accordance with Article 11 of that directive and would justify its taxation. See: Hans Markus Kofoed v Skatteministeriet (C 321/05).
}

${ }^{5}$ In that regard, the concept of 'cash payment' to the shareholders of the acquired company in the context of an exchange of shares within the meaning of Article 2 of that directive refers to cash benefits which In each case, it must be ascertained whether the charge in question has the character of a binding counter-charge to the acquisition operation. See: Hans Markus Kofoed v Skatteministeriet (C 321/05).

${ }^{6}$ Council Directive 2005/19 / EC of 17 February 2005 amending Directive 90/434 / EEC on the common system of taxation applicable to mergers, divisions, transfers of assets and exchanges of shares in companies of different Member States.

${ }^{7}$ Council Directive of 23 July 1990 on the common system of taxation applicable in the case of parent companies and subsidiaries of different Member States (90/435 / EEC). 
Member States need to set tax rules that are competition-neutral and allow companies to adapt to the requirements of the internal market in order to increase productivity and improve their international competitiveness. The result of such grouping is the formation of groups of parent companies and subsidiaries ${ }^{8}$.

Prior to the entry into force of Directive 90/435 / EEC, the existing tax rules governing relations between parent companies and subsidiaries differed in the various Member States and were generally less favorable than those applicable to parent companies and subsidiaries in the same Member State. Therefore, cooperation between companies from different Member States was less favorable compared to that of companies from the same Member State. This less favorable situation had to be eliminated by the introduction of a common system at Community level in order to facilitate the grouping of companies.

When a parent receives distributed profits from a connection with its subsidiary, the parent company must either refrain from taxing those profits or tax those profits while allowing the parent company to deduct from the amount of calculated tax the portion of corporate tax relating to those profits, and it was paid for by a subsidiary. In order to ensure fiscal neutrality, the profits that a subsidiary distributes to its parent company should be exempt from withholding tax.

The payment from the distribution of profits and the receipt of this payment by the permanent establishment of the parent company must result in the same treatment as that applied between the subsidiary and the parent company. This includes situations where the parent and the subsidiary are located in the same Member State and the permanent establishment is situated in another Member State. On the other hand, it seems that the Member State concerned can handle situations where the permanent establishment and the subsidiary are located in the same Member State, without prejudice to the application of the principles of the contract by national law.

\footnotetext{
${ }^{8}$ Within the EU, the Commission attaches great importance to simplifying and clarifying European law in order to make it clearer and more accessible to the average citizen, thus giving him new opportunities and the opportunity to exercise the special rights conferred on him by this law. This objective cannot be achieved as long as a number of regulations which have been amended several times, often very substantially, remain dispersed in such a way that they must be sought partly in the original act and partly in the subsequent acts amending it. To establish the existing rules, considerable research work is needed by comparing a number of different acts. On 8 October 2001, the Council adopted Regulation (EC) No 2157/2001 on the Statute for a European company (SE) and Directive 2001/86 / EC amending the Statute for a European company with regard to employee participation. On 22 July 2003, the Council adopted Regulation (EC) No 1435/2003 on the Statute for a European Cooperative Society (SCE) and Directive 2003/72 / EC amending the Statute for a European Cooperative Society as regards employee participation.
} 
Depending on the treatment of permanent establishments, Member States should lay down the conditions and legal instruments to protect national tax revenue and prevent the circumvention of national law, in accordance with the principles of the TEU and taking into account internationally accepted tax rules. Where groups are organized in the form of chains and the payment of profits to the parent company takes place through a chain of branches, double taxation is eliminated, with the exception of the tax credit already paid. In the case of tax credit already paid, the parent company must be able to deduct any tax paid by any subsidiary in the chain, provided that the conditions laid down in the directive are fulfilled.

\section{Harmonization of the system of taxation of interest payments and royalties of affiliated companies}

Council Directive 2003/49 / EC on the common system of taxation on interest payments and royalties between affiliated companies of different Member States has proved effective, within the limits set by its scope ${ }^{9}$. In a single market that has the characteristics of an internal market, transactions between companies from different Member States should not be treated less favorably than transactions between companies from the same Member State.

National tax rules, together with bilateral and multilateral agreements, where they exist, cannot always guarantee the elimination of double taxation, and their application often creates burdensome administrative formalities and problems with the availability of cash from these companies. It should be ensured that interest and royalties in a Member State are taxed only once. The abolition of taxation on interest payments and royalties in the Member State in which they arise, whether tax deducted at source or withholding, is the most appropriate way of eliminating the above formalities and problems and of ensuring equal tax treatment of national and cross-border transactions ; in particular, such taxes should be abolished in respect of such payments made between affiliates of different Member States and between the permanent establishments of such companies. The regime should apply only to the amounts of any interest or royalty payments agreed between the payer and the beneficial owner, unless there is a special relationship between them. It is also necessary not to prevent Member States from taking appropriate measures to prevent fraud or abuse.

\section{Harmonization of the corporate income tax base}

Companies wishing to do business across the EU across borders face significant barriers and market distortions due to 28 different corporate tax systems. Tax barriers to cross-border business are particularly large for small and medium-sized enterprises, which usually do not

\footnotetext{
${ }^{9}$ However, the first report on the application of Directive 2003/48 / EC shows that the Directive does not fully meet the objectives set out in the unanimous decisions of the ECOFIN Council of 26 and 27 November 2000. In particular, it does not cover certain financial instruments equivalent to interestbearing securities and certain indirect methods of ownership of interest-bearing securities.
} 
have the means to remedy market inefficiencies. The network of double taxation conventions between Member States does not provide an adequate solution. Current Union law on corporate taxation addresses only a small number of specific problems.

A system that would allow companies to treat EU corporate tax as a single market would facilitate the cross-border activity of resident companies in the EU and promote the goal of making the EU more competitive for international investment. Such a system would best be achieved by allowing groups of companies that are taxable in more than one Member State to regulate their tax matters in the EU on the basis of a single set of rules for calculating the tax base and to cooperate with one tax authority. These rules should also be made available to entities that are liable to pay corporate tax in the EU and are not part of the group. Thus, under the auspices of the Commission of the EU and its working bodies, the idea of creating a system of common consolidated corporate tax base (hereinafter CCCTB) emerged ${ }^{10}$.

The CCCTB is used to address some of the major tax obstacles that limit growth in the single market. In the absence of common tax rules, interactions between national tax systems often lead to over-taxation and the emergence of double taxation. Businesses face high administrative and compliance costs. This situation creates barriers to investment in the EU and results in failure to meet the priorities set out in the Europe 2020 Strategy - A Strategy for smart, sustainable and inclusive growth ${ }^{11}$. The CCCTB is an important initiative contributing to the removal of barriers to the completion of the Single Market ${ }^{12}$, which is defined in the Annual Growth Survey ${ }^{13}$ as an incentive for growth that must be pursued from the outset to accelerate growth and job creation.

The proposed corporate group taxation system would technically proceed in three steps. All taxable profits and losses of each group of companies would be aggregated, regardless of the locations of the individual group companies. The tax base of the group of companies thus determined would be attributed to the individual companies of the group by means of a distribution formula. The tax base attributed to the individual company of the group would be taxed at the national tax rate of the country in which the company is located. Member States would remain independent in setting the tax rate for the established share of the profits of an undertaking located in its territory.

${ }^{10}$ Aujean M., (2008) The CCCTB Project and the Future of European Taxation v Lang M. et.al., Common Consolidate Corporate Tax Base, Linde Verlag, Vienna, pp. 11-37.

${ }^{11}$ Communication from the Commission "EUROPE 2020 - A strategy for smart, sustainable and inclusive growth", COM (2010) 2020 of 3 March 2010.

${ }^{12}$ Communication from the Commission "Towards a Single Market Act - Towards a highly competitive social market economy - 50 proposals to improve joint work, business and exchanges", COM (2010) 608 of 27 October 2010.

${ }^{13}$ Communication from the Commission "Annual Growth Survey: Promoting EU action for a comprehensive crisis response", COM (2011) 11 of 12 January 2010. 
A common approach would ensure the coherence of national tax systems on the basis of a common tax base, but would not prejudice the rights of States to set the tax rate. Each Member State will apply its own tax rates to its share of taxpayers' tax bases. Differences in the determination of the tax rates of individual Member States allow for a degree of tax competition to be maintained internally. It enables Member States to take into account, in tax planning, both their competitiveness in the EU internal market and the regulation and balancing of the budgetary needs of each Member State ${ }^{14}$.

In particular, CCCTB contributes to reducing tax barriers and administrative burdens, making it easier and less costly for SMEs to expand their activities across the EU. The approach of small and medium-sized enterprises to the CCCTB means that SMEs operating across borders use their CCCTB rule to calculate their tax base. In the case of accession to the $\mathrm{CCCTB}^{15}$. SMEs would have less compliance costs, which would have a positive impact on the decision to commercially expand to another Member State.

The CCCTB introduces a single set of tax rules in the EU Member States and uses only one tax administration model. A company opting for the CCCTB ceases to be subject to the national tax regime in respect of all tax matters governed by the CCCTB common rules. A company that will not qualify or opt for the CCCTB system is still subject to the rules applicable in national tax law.

The introduction of the CCCTB could lead to problems related to contracts of jurisdiction and to the taxation of revenue generated by European companies outside the EU or outside the CCCTB. Separate profit-sharing practices would be applied in relation to non-EU countries, this would probably lead to the parallel use of different systems. This would put an administrative burden on businesses, reducing the benefits of CCCTB taxation. The question is to what extent the high mobility of capital, globally, diminishes the benefits of tax coordination within the $\mathrm{EU}^{16}$.

A more important advantage of the CССТВ is the ability to determine profits and losses at the level of an international company, which would cover the losses of businesses at EU level. The profits and losses of a group of companies would not be separated by country in which individual subsidiaries of the group are located, but at the outset all taxable profits and losses,

${ }^{14}$ Aujean M., 2008, p 11-37.

${ }^{15}$ Neale T., (2008) CCCTB: How fare we got and what are the next steps? v Lang M. et.al., Common Consolidate Corporate Tax Base, Linde Verlag, Vienna, , pp. 63-93.

${ }^{16}$ Martini Jimenez A. in Calderon Carrero J. M., (2008) Administrative Cooperation - Exchange of Information in the Context of the CCCTB v Lang M. et.al., Common Consolidate Corporate Tax Base, Linde Verlag, Vienna, pp. 93-112. 
regardless of the location of individual companies in the group, would be consolidated. Thus, the overflow of profits between group companies would not make sense, since the introduction of such a system would also eliminate the need to set transfer prices for transactions between individual CCCTB companies ${ }^{17}$.

The taxpayer's income must be taxable unless they are explicitly exempted. The CCCTB system excludes dividend income, proceeds from the disposal of shares of a non-group company and profits from permanent establishments abroad. Most Member States exempt dividends and proceeds from the disposal of shares when exempting double taxation, thus avoiding the deduction of tax paid abroad by taxable persons, especially if such entitlement is subject to corporate tax by paid by the dividend company. Exemption from income from abroad should also be simplified. Taxable income should be reduced by operating expenses and certain other items. Deductible business expenses should typically include all costs associated with sales, as well as expenses related to the generation, maintenance and insurance of income. Research and development costs and expenses incurred in raising equity or debt for business purposes should be deducted. A list of non-deductible expenditure should also be drawn up ${ }^{18}$. Tangible and intangible fixed assets should be depreciated separately, while the rest should be included in the group of assets. Group depreciation is a simplification for tax authorities and taxpayers as it eliminates the need to draw up and maintain a list for each type of fixed asset and its useful life ${ }^{19}$.

In the case of loss carry-over, taxable persons shall be allowed to carry forward the loss for an indefinite period without transferring the loss to a prior period. As the loss is carried forward to pay the taxpayer a tax on his real income, there is no reason to limit the period for carrying forward. The carry-over of losses to a previous period is relatively rare in Member States' practice and causes excessive complexity ${ }^{20}$.

Consolidation is an essential element of the CCCTB, since the main tax obstacles facing EU companies can only be addressed in this context. The consolidation eliminates the formalities regarding intra-group transfer prices and double taxation. In addition, the loss incurred by taxpayers is automatically offset by the profits made by other members of the same group.

${ }^{17}$ Tenore M., (2008) Requirements to Consolidate and Changes in the Level of Ownership v Lang M. et.al., Common Consolidate Corporate Tax Base, Linde Verlag, Vienna, pp. 63-93.

${ }^{18}$ Navarro A. in Soter Roch M. T., (2008) Mesaurment of Income and Expenses v Lang M. et.al., Common Consolidate Corporate Tax Base, Linde Verlag, Vienna, pp. 421-441.

${ }^{19}$ Litwinczuk H. in Supera - Markowska M., (2008) Depreciation Rules in CCCTB v Lang M. et.al., Common Consolidate Corporate Tax Base, Linde Verlag, Vienna, pp. 305-323.

${ }^{20}$ Moreno Gonzales G. in Sanz Diaz-Palacios J. A., (2008) The CCCTB: Treatment of Losses v Lang M. et.al., Common Consolidate Corporate Tax Base, Linde Verlag, Vienna, pp. 441-460. 
Consolidation should include rules for the distribution of results among the Member States in which the members of the group have their business units ${ }^{21}$.

The distribution formula of the consolidated tax base contains three equally weighted factors (labor, assets and sales). The labor factor is calculated on the basis of pay for work and the number of employees (each item represents half). The asset factor consists of all tangible fixed assets. Intangible and financial assets should be excluded from the formula because of their mobile nature and the risks of evading the system. Finally, sales must be taken into account to ensure fair participation by the Member State of destination. These factors and weightings must ensure that profits are taxed where they are earned. As an exception to the general principle, where the result of the distribution does not fairly represent the scope of the business activity, a safeguard clause provides for an alternative method $^{22}$.

It also lays down rules on the reorganization of undertakings which adequately safeguard Member States' taxation rights. In the event that a company joins the group, the market loss before consolidation should be carried forward to the future to write off the taxpayer's distributed share. If a company exits the group, it will not be allocated losses incurred during the consolidation period. Transactions between a taxpayer and an affiliate that is not a member of the same group subject to price adjustment in accordance with an independent market principle, which is a generally valid criterion.

In the administrative area, groups of companies are allowed to cooperate with only one tax administration (principal tax authority), which is the tax administration of the Member State where the parent company of the group (principal taxpayer) is resident for tax purposes. A general anti-abuse rule is also included, supplemented by measures to limit certain types of abuse. These measures include restrictions on the deductibility of interest paid to tax-exempt affiliates resident in a low-tax country outside the EU who does not exchange information with the paying Member State on the basis of an agreement comparable to Council Directive 2011/16 / EU on mutual assistance the competent authorities of the Member States in the field of direct taxation and taxation of insurance premiums, and regulations on foreign subsidiaries ${ }^{23}$.

\footnotetext{
${ }^{21}$ Oestreicher A., (2008) CCCTB - Methods of Consolidation v Lang M. et.al., Common Consolidate Corporate Tax Base, Linde Verlag, Vienna, pp. 517-547.

${ }^{22}$ EU Commission, CCCTB; Possible elements of the sharing mechanism, Brussels, 13 November 2007.

${ }^{23}$ Amparo Grau Ruiz M., (2008) Administrative Cooperation - Excange of Information in the Context of the CССТВ v Lang M. et.al., Common Consolidate Corporate Tax Base, Linde Verlag, Vienna, pp. 945-957.
} 


\section{Conclusion}

The disadvantages of tax harmonization can be characterized by tax competition, as countries with high prosperity and, consequently, higher taxes, rich countries that can offer investors better infrastructure, an experienced and skilled workforce, a better business, legal and social environment, and public services. With these options, countries can raise tax rates while still maintaining mobile factors within borders. Even the uniformity of the tax rate would not have complete positive effects, since the peripheral countries would no longer have any competitive advantage, given that taxes in the developed countries would be equal. This would result in a strong concentration of companies in more developed countries and a loss of investors in countries where investments are necessary. However, I have to point out that tax competition also produces positive results, as countries strive to make the tax sector more efficient and thus indirectly require less tax revenue and burden both individuals and legal entities.

\section{References}

Amparo Grau Ruiz M., (2008) Administrative Cooperation - Excange of Information in the Context of the CCCTB in Lang M. et.al., Common Consolidate Corporate Tax Base, Linde Verlag, Vienna, pp. 945-957.

Auerbach A. J., The Future of Capital Income Taxation, Fiscal Studies 27 (4), p. 399-420.

Aujean M., (2008) The CCCTB Project and the Future of European Taxation in Lang M. et.al., Common Consolidate Corporate Tax Base, Linde Verlag, Vienna, pp. 11-37.

Communication from the Commission "Annual Growth Survey: Promoting EU action in response to the crisis", COM (2011) 11 of 12 January 2010.

Communication from the Commission "EUROPE 2020 - A strategy for smart, sustainable and inclusive growth", COM (2010) 2020 of 3 March 2010.

Communication from the Commission "Towards a Single Market Act - Towards a highly competitive social market economy - 50 proposals to improve joint work, business and exchanges", COM (2010) 608 of 27 October 2010.

Council Directive 2005/19 / EC of 17 February 2005 amending Directive 90/434 / EEC on the common system of taxation applicable to mergers, divisions, transfers of assets and exchanges of shares in companies of different Member States.

Council Directive of 23 July 1990 on the common system of taxation applicable in the case of parent companies and subsidiaries of different Member States (90/435 / EEC).

Deweraux MP, Griffith R, Klemm A., (2002) Corporate Income Tax Reforms and International Tax Competition, Economic Policy, 35, p. 451-495.

EU Commission, CCCTB; Possible elements of the sharing mechanism, Brussels, 13 November 2007.

Kind H.J., Middelfart K.H., Schjelderup G., Corporate Tax System, Multinational Enterprises and Economic Integration, Journal of International Economics, Elsevier 65 (2), pp. 507-521. Litwinczuk H. and Supera - Markowska M., (2008) Depreciation Rules in CCCTB in Lang M. et.al., Common Consolidate Corporate Tax Base, Linde Verlag, Vienna, pp. 305-323. 
Martini Jimenez A. and Calderon Carrero J. M., (2008) Administrative Cooperation - Exchange of Information in the Context of the CCCTB in Lang M. et.al., Common Consolidate Corporate Tax Base, Linde Verlag, Vienna, pp. 93-112.

Moreno Gonzales G. and Sanz Diaz-Palacios J. A., (2008) The CCCTB: Treatment of Losses in Lang M. et.al., Common Consolidate Corporate Tax Base, Linde Verlag, Vienna, pp. 441460.

Navarro A. and Soter Roch M. T., (2008) Mesaurment of Income and Expenses in Lang M. et.al., Common Consolidate Corporate Tax Base, Linde Verlag, Vienna, pp. 421-441.

Neale T., (2008) CCCTB: How fare we got and what are the next steps? in Lang M. et.al., Common Consolidate Corporate Tax Base, Linde Verlag, Vienna, pp. 63-93.

Oestreicher A., (2008) CCCTB - Methods of Consolidation in Lang M. et.al., Common Consolidate Corporate Tax Base, Linde Verlag, Vienna, pp. 517-547.

Tenore M., (2008) Requirements to Consolidate and Changes in the Level of Ownership in Lang M. et.al., Common Consolidate Corporate Tax Base, Linde Verlag, Vienna, 2008, pp. 6393. 